\title{
INTERPRETATION OF THE MOST IMPORTANT NOTIONS OF SOCIAL INEQUALITIES OVERT IN THE EDUCATIONAL SYSTEM
}

\author{
Author: \\ Norbert Tóth \\ University of Debrecen \\ Faculty of Child and Special Needs Education \\ (Hajdúböszörmény, Hungary) \\ E-mail adress of the first author: \\ tothnorbert0723@gmail.com
}

\author{
Lectors: \\ Zoltán Györgyi (PhD.) \\ University of Debrecen \\ (Hungary) \\ Antal Kiss Lovas (PhD.) \\ University of Debrecen \\ (Hungary)
}

Tóth N. (2019): Interpretation of the most important notions of social inequalities overt in the educational system. Különleges Bánásmód, 5. (1). 83-87. DOI 10.18458/KB.2019.1.83

\begin{abstract}
Present paper focuses on the social inequalities that are mainly manifested in the educational system. Therefore, I aim at reflecting on the sociological definitions that codify the subject in a theoretical context. The theoretical background of the study comprises the subsequent notions: equality and equity, inclusive society and education, bicultural socialization and the relation between social mobility and school.
\end{abstract}

Keywords: education, equality, inclusion, socialization

Disciplines: pedagogy, sociology

\begin{abstract}
Absztrakt
A TÁRSADALMI EGYENLŐTLENSÉGEK OKTATÁSI RENDSZERBEN MEGJELENŐ LEGFONTOSABB FOGALMAINAK INTERPRETÁCIÓJA

A tanulmány azon társadalmi egyenlőtlenségekkel foglalkozik, amelyek elsősorban az oktatási rendszerben manifesztálódnak. Ennek értelmében a dolgozat arra vállalkozik, hogy azokat a szociológiai fogalmakat járja körül, amelyek a témát elméleti kontextusba ágyazzák. A tanulmány elméleti vázát a következő főbb terminológiák képezik: esélyegyenlőség és méltányosság, inkluzív társadalom és oktatás, bikulturális szocializáció, valamint a társadalmi mobilitás és az iskola relációja.
\end{abstract}

Kulcsszavak: oktatás, inkluzió, szocializáció

Diszciplínák: pedagógia, szociológia

\section{Theoretical framework of equality}

In accordance with the theories of sociology, present-day modern societies may be considered as democratic if their leaders do their bests to provide the individual with subsidies and possibilities that help to overcome social disadvantages and to establish the framework of social mobility (Varga, 2018).

It is inevitable to define the notion of equality to delineate the theoretical framework of the above idea. The explanation of the notion shall be carried out with due care, since the interpretation shall be realized in a twofold level as distinction shall be made between equality and equity (Varga, 2015).

Equality means that all citizens are provided with equal access to material and immaterial goods in a society. Moreover, the notions of equal treatment and prohibition of discrimination belong to the idea of equality. All in all, equality guarantees a social minimum according to which no one can be discriminated due to his/her real or deemed attributes. In Hungary, this is codified in Act CXXV of 2003, while it is regulated by Article 14 of European Conventions on Human Rights at an international level (Papp, 2012).

The notion of equity, however, emphasizes that the elimination of factors that are the main causes for social disadvantages is not sufficient as the conditions of real equality are not provided by such elimination. "Besides the equity and the ban on discrimination, it means the realization of supporting factors that are measures and acts against inequalities observed in the society" (Varga, 2015. 243.) This implies that the set of conditions required for the supporting tools is not provided automatically; rather uninterrupted and dynamic acting is needed. 
In practice, efforts are required to provide those in inequality with goods.

The elaborated definitions of equity is of importance as it has more aspects other than human rights - it also plays a significant role in measuring the success of educational systems and students. This is due to the more and more popular international approach according to which the quality education shall be interpreted within the framework of efficacy, competence and equity.

Moreover, I think it is important to highlight that the notion of equality is overshadowed in the social discourse and the characteristic features and measures that are related to the set of conditions of equal opportunities are now assigned to the notion of equity.

\section{Equality and equity from the perspective of educational system}

Pierre Bourdieu studied the problem of the recurring social inequalities and the role of the school in this phenomenon. Bourdieu draws the attention to the fact that certain social inequalities are generally converted into school inequality and the different educational levels are coupled with different career chances (Bourdieu, 1997). Moreover, educational system has two basic functions, the French scholar states. One is to preserve the characteristics features of the own system and the other is to safeguard the basic mechanisms of the concerned social system. This means that the educational system contributes to the recurring of classes in a form in which the school seemingly maintains its autonomy. This means that equal access to studying and education is provided for all individuals of the society, even at the level of the legal provisions, however, there are certain latent mechanisms in the relation of the cultural capital of the family that greatly determines the successful advancement of the student in the schools (Pusztai, 2015).

In this case, the theory of the implementation of equality means that everybody can enroll in the educational system, however, at the same time, students with low social status are only successful if their advancement are accompanied by certain supporting, that is to say, equity services.

This conception occurred in the American social discourse in the 1970's. According to this, the equality theory regarding enrolling in the educational system is approached by the perspective of cultural differences between the school and certain families. For the success of the student, the characteristics of the familial socialization shall be considered as significant factors, and, moreover, that fact that how the educational systems are related to it.
The biggest problem occurs when the difference between the set of values of the family and the school is rather significant. In this case, the solution is to elaborate interventions that provide the approach of the two distinct cultural spaces towards each other. According to Adler, this process is called bicultural socialization (Varga, 2015).

The uniqueness of bicultural socialization lies within the fact that it focuses on the parallel impact system of the socialization in the institutional space (family and school). According to this, the successful school advancement and successful social integration depend on the extent of the interrelation between the two socializations spaces. In Aranka Varga's interpretation: "In the dual process of bicultural socialization, the impact of public education (kindergarten, school) is overt besides acquiring the cultural features of familial socialization, where the culture of the majority society is the subject of the socialization process. Regarding this duality, the theory of bicultural socialization unambiguously declares that there are certain familial socializations whose cultural content is slightly overlapping with the cultural space of the school." (Varga, 2015. 248.)

In the case of such family, progress is only made if the actors of the bicultural field consider the cross-compliance of the two distinct spaces as their common role. Two actors play an important role in this process. One is the mediator who is familiar with the entire educational system and school and provides the most important information from firsthand. Teachers are typically considered as mediators. They are able to establish contact with the family, that is to say, with the primary socialization space. After getting familiar with the cultural characteristic features of the family, the teacher tries to carry over the most important ones to the school, to widen the overlapping between the socialization space of the family and school.

Another significant actor of the bicultural socialization space is the translator. The translator is from a family in which the culture is different from that of the school, however, despite such differences, this person was successful in the socialization space of the school. Therefore, the translator is able to convey the value system of the secondary socialization space to his or her community. This role mainly relies on his or her credibility. The set of tools applied include direct mediation and unnoticed transfer of patterns (Fehérvári, 2015).

I think it is important to emphasize that bicultural socialization is a two-way process and it is ordinary that conflicts may arise upon correlating the two distinct cultures. Therefore, uninterrupted and indirect communication and cooperation shall be 
regarded as one of the most important factors of bicultural socialization.

\section{Mechanisms of inclusivity reducing social equality}

In the regard of the theory of bicultural socialization, I think it is important to provide an overview and analysis on the theoretical framework and practical implementation of inclusion or inclusivity. This approach is relevant as inclusion implies a certain acceptation and such process is inevitable to achieve the goal set by bicultural socialization the widening of the overlapping between the primary and secondary socialization space.

Prior to defining the concept of inclusion and inclusive social education, it is inevitable shed light on the notion of multiculturalism as the concept of inclusion is derived from the notion multiculturalism (Torgyik, 2015). Multiculturalism places the main emphasis on the assumption that social diversity shall be considered as a value. Moreover, the cohabitation of different cultures and identities is to be encouraged. Besides these, the handling of the multicultural society from equality perspectives and the intercultural pedagogy are of importance as success in school provided by equal focus on every student.

Consequently, inclusion draws inspiration from the notion of multiculturalism, however, its interpretation was narrower in the beginning. Originally, inclusion meant the efforts on the successful institutional education of the disabled students. That is to say, interventions related to integrative school intervention, such as supporting adapting to the students with special needs, were considered as inclusions (Papp, 2012).

Lately, the notion of inclusion has been modified from multiple aspects and now can be more widely interpreted. The main change is that the number of individuals and groups rose who are in the focus of acts carried out for the purposes of inclusion. The reasons for this are as follows: "... without the customized changes of the environment, groups other than the disabled are endangered by the exclusion processes. Thus the activities successfully supporting inclusion, such as preventing school dropout or eliminating the limits of access, gradually cover individuals and groups that are frequently excluded from education or certain segments of the society" (Varga, 2015. 250.)

The widening of the concept of inclusion not only meant that the focus was directed towards a wider target group. The focus was excerpted from the framework of the educational system and an approach that can be interpreted at social level was formed, which occurs as the idea of social inclusion in the scientific discourse. This term is often related with the notion of integration as in certain cases they replace each other and are in a complementary distribution.

However, the formation of social inclusion was not by chance. The European Union played in important role in establishing and spreading the concept. In the beginning of the 2000's, the declaration of social cohesion, that is to say, the conflict-free cohabitation of different social classes was one of the most important principles of the EU.

The main field of the above-described social implementation of the notion is in the educational institutions. In accordance with the basic principle of inclusion, one of the major starting points of host society is the school as activity mechanism that is an "activity with the community, in the community and for the community" may be realized mostly in schools.

The practical implementation of inclusive education was facilitated by the guidelines of UNESCO published in 2005. Among such policies, one openly declares that inclusion unconditionally accepts diversity and is not restricted to special education and its reforms. The directives are not only aimed at providing the improvement of the educational environment of disabled children but also at granting quality educational environment to all students.

Apart from the core guidelines, the UNESCO report defines four core principles of the inclusive education. First, inclusion is a never-ending process and is able to provide answers for the multitude of problems detected in schools. Second, inclusion strives for gathering as much information and data as possible to be able to detects the problems after the evaluation. Third, the presence of inclusion in schools induces a measurable performance for all students. Fourth, inclusion pays special attention to the successful school advancement of students who are especially endangered by exclusion and its consequences.

\section{The relation of social mobility, equality and school}

It is an excellent question that what are the reasons behind the fact both the European Union and UNESCO have organized programs against school inequalities. The more improved a society is, the more education defines the position of the individual in the social inequality system (Ferge, 1980). Therefore, the relation between education and equality was in the focus of social scientific research between the two world wars. The majority studies on the subject reflects on the fact that indi- 
viduals from different social classes have different chances in enrolling in certain types of school of the educational system. Lawton highlights the situation of the workers to introduce the problem (Lawton, 1974) as it is much harder for the children of the workers to be admitted in grammar schools. Moreover, students from lower social classes tend to dropout from these schools.

Certain researchers, however, maintain a different approach towards the issue. James Samuel Coleman, for instance, defines the equality of education chances as one factor of efficacy. In accordance with this, Coleman came to the conclusion that the majority of scientific investigations pays too much attention to the role of school (Coleman, 1966). It is rather problematic as the school has no significant effect on the advancement of students, which is more likely determined by the social status of the parents. I think critique shall be applied in the regard of Coleman's approach, especially when the socially selective characteristic of the Hungarian educational system is taken into consideration.

Studies on social equality and school were first launched in the 1960's in Hungary, thanks to Zsuzsa Ferge's efforts. She destroyed the myth about the social equality in Hungary. Her researches revealed that there are strata in the Hungarian society that have better chances and there are other groups that have restricted access to advancement. Everything depends on the concentration of knowledge and power (Ferge, 1980).

It shall be emphasized, however, that status due to belonging to any social classes is not static and the possibility of social mobility is overt. As for the first step, the notion of social mobility shall be defined. The explanation of the concept, however, is rather problematic as we do not possess a framework system that provides exact information about the fact that at which point we may talk about social mobility. Notwithstanding, we can define particular factors that directly or indirectly affect the process; these are the political and economic changes, individual or family events.

The interpretation of social mobility may be approached from multiple directions. On the one hand, there is an intergeneration mobility that reflects on the fact that how the individual moves in the social hierarchy compared to his or her parents. On the other hand, intrageneration mobility reveals the mobility of the individual in the career field. Most of the sociologists think that intergeneration mobility is more frequent in stable societies (Ferge, 1980).

One important distinction between intergeneration and intrageneration mobility is that the comparison of intergeneration mobility among differ- ent countries can be measured in a more precise way. There is also the phenomenon of circular mobility when certain individuals switch their places.

It is possible to allude to the extent of the movements within the society. In accordance with this, a distinction is made between individual and collective mobility. In the case of the first, social conditions remain the same, however, in the case of the latter, these conditions are somewhat altered.

Regarding social mobility, Anikó Fehérvári draws the attention to the interpretation by Lipset and Bendix. The two researchers discussed the question of measuring mobility, that is to say, to what we compare mobility (Fehérvári, 2015). They think that social mobility shall be analyzed in time dimension or comparison as a certain society can be adequately described if it is compared to its earlier epoch or to a different country. Moreover, the scholars refer to a third alternative, the model of equal possibilities. According to this model, the ratio of mobility shall be disregarded and the inequality of possibilities leading to this road shall be taken into consideration instead.

Finally, the name of Sorokin shall not be forgotten when discussing social mobility. He thought that vertical mobility is present in all societies. The education system of the Church or military is included in the set of tools of such mobility, however, the most important one is the school. Sorokin compared school to an elevator that carries the people up and down. He emphasizes that there are societies in which the elevator starts from the very bottom, however, there are certain other societies where it starts from the middle and the people at lowest classes of society have no access to such elevator at all (Sorokin, 1998).

Moreover, school is more than an educational institution, Sorokin states, as this is the venue where the social positions are selected. In certain cases, passing exams and meeting different requirements are used to select and distribute people to future social positions. This is of high importance, Sorokin argues, because if the individual is unsuccessful in the school, $\mathrm{s} /$ he will less likely to find another mobility channel apart from school.

\section{REFERENCES}

Bourdieu P. (1997): Gazdasági tôke, kulturális tőke, társadalmi tőke. In Angelusz R. (Ed.), A társadalmi rétegzódés komponensei. Budapest: Új Mandátum Kiadó.

Coleman, J. (1966): Equality of Educational Opportunity. Government. Washington DC: Printing Office.

Fehérvári A. (2015): Társadalmi mobilitás és az iskola. In Varga Aranka (Ed.). A nevelésszociológia 
alapjai. Pécs: Pécsi Tudományegyetem BTK Neveléstudományi Intézet Romológia és Nevelésszociológia Tanszék.

Ferge Zs. (1980): Társadalompolitikai tanulmányok. Budapest: Gondolat Könyvkiadó.

Lawton D. (1974): Társadalmi osztály, nyelv, oktatás. Budapest: Gondolat Kiadó.

Papp G. (2012): Az integráció, inklúzió fogalmak tartalmi elemzése gyógypedagógiai megközelítésben nemzetközi és magyar színtéren. Gyógypedagógiai Szemle, 4-5. sz. 295-304.

Pusztai G. (2015): Tőkeelméletek az oktatáskutatásban. In Varga Aranka (Ed.), A nevelésszociológia alapjai. Pécs: Pécsi Tudományegyetem BTK Neveléstudományi Intézet Romológia és Nevelésszociológia Tanszék.

Sorokin P. A. (1998): Az egyének társadalmi rétegenkénti minősítésének, kiválasztásnak és elosztásának mechanizmusai. In Róbert Péter
(Ed.): A társadalmi mobilitás: Hagyományos és új megkëzelitések. Budapest: Új Mandátum Kiadó

Torgyik J. (2015): Multikulturalizmus, interkulturális nevelés. In Varga Aranka (Ed.), A nevelésszociológia alapjai. Pécs: Pécsi Tudományegyetem BTK Neveléstudományi Intézet Romológia és Nevelésszociológia Tanszék.

Varga A. (2015): Esélyegyenlőség és inkluzió az iskolában. In Varga Aranka (Ed.), A nevelésszociológia alapjai. Pécs: Pécsi Tudományegyetem BTK Neveléstudományi Intézet Romológia és Nevelésszociológia Tanszék,

Varga A. (2018): A rendszerváltás gyermekei. Pécs: Pécsi Tudományegyetem BTK Neveléstudományi Intézet Romológia és Nevelésszociológia Tanszék. 